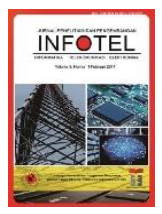

\author{
JURNAL INFOTEL \\ Informatika - Telekomunikasi - Elektronika
}

Website Jurnal : http://ejournal.st3telkom.ac.id/index.php/infotel

ISSN : 2085-3688; e-ISSN : 2460-0997

\title{
Simulasi Sistem Parkir Mal Berbasis Lokasi Kunjungan User Menggunakan Arduino Uno dan RFID
}

\author{
Randy $^{1}$, Sean Coonery Sumarta ${ }^{2}$, Erick Alfons Lisangan ${ }^{3}$ \\ 1,2,3 Jurusan Teknik Informatika, Fakultas Teknologi Informasi, Universitas Atma Jaya Makassar \\ 1,2,3 Jalan Tanjung Alang No. 23, 90134, Makassar, Indonesia \\ Email korespondensi: erick_lisangan@lecturer.uajm.ac.id
}

Dikirim 14 Juli 2017, Direvisi 29 Juli 2017, Diterima 03 Agustus 2017

\begin{abstract}
Abstrak - Kehadiran mal memungkinkan masyarakat untuk memenuhi kebutuhannya hanya pada satu lokasi saja. Layanan parkiran merupakan salah satu layanan yang terpenting pada mal. Kendala yang sering ditemukan pada layanan parkir mal adalah pengunjung kesulitan mencari lokasi lot parkir yang kosong. Pengunjung ketika ingin mengunjungi sebuah outlet tertentu cenderung memilih pintu yang terdekat agar tidak membutuhkan waktu yang lama untuk berjalan. Dalam memperoleh lokasi parkir, pengunjung terkadang harus berputar terlebih dahulu untuk mendapatkan tempat parkir yang diinginkan. Berdasarkan permasalahan tersebut, sebuah sistem dirancang untuk dapat memberikan rekomendasi lokasi lot parkir terdekat dari lokasi kunjungan. Setiap lot dan outlet akan diberikan titik koordinat yang digunakan untuk menghitung jarak terdekat dengan menggunakan Euclidean Distance. Arduino Uno digunakan untuk mengendalikan sensor Light Dependent Resistor (LDR), buzzer, dan Radio Frequency Identification (RFID) reader. Pengujian sistem yang dirancang dilakukan terhadap 10 skenario. Hasil pengujian menunjukkan persentase ketersediaan lot parkir terdekat dengan outlet yang akan dikunjungi adalah sebesar $100 \%$. Hal ini disebabkan karena sistem dirancang dengan mempertimbangkan jarak antara lot dengan outlet tujuan dan status ketersediaan lot terdekat. Apabila lot terdekat telah ditempati maka sistem secara otomatis akan memberikan rekomendasi lot terdekat berikutnya kepada pengguna.
\end{abstract}

Kata kunci - sistem parkir mal, lokasi kunjungan, euclidean distance, RFID

\begin{abstract}
The presence of the mall allows people to make ends meet only at one location. The park service is one of the most important services in the mall. The visitor often face some problem, such as very difficult in finding the location of an empty parking lot. Visitors tend to choose the nearest door so that they do not require a long time to walk. In obtaining the location of parking, visitors sometimes have to spin in advance to obtain the desired parking spot. Based on these problems, a system designed to provide recommendations on the location of the nearest parking lot to the outlet that user want to visit. Every parking lot and outlet will be given the coordinates that will be used to calculate the distance by using Euclidean distance. Arduino Uno is used to control Light Dependent Resistor (LDR) sensors, buzzer, and Radio Frequency Identification (RFID) reader. The test of designed system involves 10 different scenarios. The result of designed system testing show the percentage of availability of the nearest parking lot with outlets to be visited is $100 \%$. This is due to the system is designed by considering the distance between the lot with the destination outlet and the nearest lot availability status. If the closest lot was occupied, the system will automatically give recommendations next closest lot to the user.
\end{abstract}

Keywords - mall parking system, outlet location, euclidean distance, RFID

\section{PENDAHULUAN}

Seiring dengan kemajuan jaman dimana masyarakat semakin membutuhkan sesuatu yang efisien, maka muncul mal dengan konsep dapat memenuhi semua kebutuhan masyarakat dalam satu tempat. Dengan adanya mal, masyarakat dapat berbelanja, berjalan-jalan, menikmati hiburan, makan, dan berbagai macam kegiatan lain [1]. Dalam perannya sebagai pusat keramaian maka pengelola mal akan memberikan berbagai layananan kepada pengunjung seperti toilet, ruang menyusui, ruang beribadah sampai layanan parkiran. 
Layanan parkiran merupakan salah satu layanan yang terpenting dikarenakan hal yang pertama yang dilakukan oleh pengunjung ketika berkunjung ke sebuah mal yakni memarkir kendaraannya [2]. Pada parkiran tersebut terdapat beberapa pintu yang menghubungkan langsung kedalam mal. Pintu tersebut mewakili lokasi tujuan dari pengunjung.

Alur parkir pengunjung pada saat masuk ke dalam sebuah mal yakni datang ke pos, mengambil karcis, mencari lokasi parkir dan memilih tempat yang tersedia. Pada saat pengunjung di parkiran maka terdapat petugas parkir yang akan menunjukkan lokasi lot parkir yang kosong.

Penelitian mengenai sistem parkir telah banyak dilakukan pada [3][4][5][6][7][8]. Sistem informasi dirancang untuk membantu administrasi penitipan atau parkir motor di terminal [3] dimana petugas akan menginput secara manual informasi data kendaraan pengguna ke dalam sistem. Kelemahan yang dimiliki dari penelitian tersebut adalah petugas akan kesulitan dalam melakukan penginputan apabila banyak motor yang hendak memarkir kendaraannya. Sistem perparkiran pada universitas dirancang dengan memanfaatkan teknologi barcode [4] untuk menghindari penginputan data kendaraan secara manual.

Sistem parkir dikembangkan dengan menggunakan RFID untuk proses identifikasi dan pendataan kendaraan [5]. Radio Frequency Identification (RFID) merupakan teknologi identifikasi yang relatif fleksibel, mudah digunakan dan cocok untuk dipakai pada sistem yang berjalan secara otomatis dengan menggunakan sarana yang disebut label RFID atau transponder (tag RFID) [9][10]. Tag RFID dapat berupa stiker, kertas atau plastik dengan beragam ukuran. Di dalam setiap tag ini terdapat chip yang mampu menyimpan sejumlah informasi tertentu [11]. Label atau kartu RFID adalah sebuah benda yang ditempatkan pada sebuah produk, hewan atau bahkan manusia dengan tujuan untuk dilakukan identifikasi menggunakan gelombang radio [10].

Pada sistem parkir [5], RFID digunakan sebagai pengganti identitas kendaraan sehingga saat kendaraan masuk/keluar pendataannya dilakukan secara otomatis tanpa perlu petugas menginput data kendaraan. Kelemahan dari kedua sistem tersebut adalah tidak adanya informasi mengenai lokasi parkir yang kosong.

Sebuah aplikasi parkir dikembangkan [6] yang memungkinkan petugas pos masuk dapat memilih lokasi parkir yang kosong untuk setiap kendaraan yang masuk. Pada aplikasi tersebut, lokasi parkir akan berwarna merah apabila telah ditempati oleh kendaraan. Sistem parkir memanfaatkan mikrokontroler dan sensor Ping Ultrasonik dikembangkan pada [7]. Pada sistem parkir tersebut, sensor ultrasonik diletakkan di bagian atas lot parkir dan akan memberikan informasi apabila lot parkir telah terisi atau masih kosong. Sistem parkir otomatis dikembangkan [8] yang memungkinkan pengunjung cukup menempatkan kendaraan pada lokasi yang ditentukan, kemudian lift parkir yang dikembangkan secara otomatis akan memarkir ke lokasi yang kosong Ketiga penelitian tersebut mampu memberikan informasi atau bantuan kepada pengunjung dalam mencari lokasi parkir. Kelemahan yang dimiliki adalah lokasi parkir hanya sebatas lot yang kosong saja tanpa mempertimbangkan outlet yang akan dikunjungi oleh pengunjung.

Pengunjung ketika ingin mengunjungi sebuah outlet tertentu maka harus memilih pintu yang terdekat agar tidak membutuhkan waktu yang lama untuk berjalan. Akan tetapi kadang area parkir tersebut sudah terisi atau sedang diisi oleh kendaraan lain sehingga pengunjung harus berputar untuk mencari atau menunggu pengguna lain untuk keluar. Hal tersebut berdampak terjadinya kemacetan antrian pada tempat parkir yang menimbulkan kerugian berupa pencemaran udara. Kualitas udara dalam ruang parkir menjadi hal yang sangat penting karena ruang parkir biasanya tertutup dengan sistem ventilasi yang sering kali tidak memadai. Polusi udara yang berasal dari kemacetan di tempat parkir dapat membahayakan kesehatan petugas-petugas yang bekerja di ruang parkir basement itu apalagi jika diakumulasikan dalam rentang waktu yang cukup lama [12]. Untuk mengatasi masalah tersebut maka diperlukan sebuah sistem parkiran yang dapat memberikan lokasi tempat parkir berdasarkan lot parkir yang kosong menurut lokasi kunjungan pengunjung mal.

Pada penelitian ini akan mengatasi permasalahan parkir bagi pengunjung, dengan membuat sistem peparkiran yang daapat memberikan lot parkir kepada pengunjung berdasarkan lokasi kunjungan. Setiap lot dan outlet akan diberikan titik koordinat yang akan digunakan untuk menghitung jarak dengan menggunakan perhitungan Euclidean distance. Lot parkir dengan jarak terdekat terhadap outlet tujuan menjadi lot parkir yang direkomendasikan kepada pengunjung.

Sebagai pendukung dari solusi permasalahan, penelitian ini akan memanfaatkan fungsi dari Arduino Uno. Arduino Uno digunakan untuk mengendalikan seluruh rangkaian yang terdiri dari beberapa sensor dan menyimpan program untuk menangani data dari sensor [13]. Pada penelitian ini, Arduino Uno bertugas untuk mengendalikan sensor Light Dependent Resistor (LDR), buzzer, dan Radio Frequency Identification (RFID) reader. Pada penelitian ini, sensor LDR digunakan untuk memperoleh kondisi apakah sebuah lot telah terisi atau masih kosong. Kartu RFID pada penelitian ini akan berfungsi sebagai pengganti karcis dan sebagai kunci lot yang akan menjadi penanda pemilik lot tersebut. 


\section{METODE PENELITIAN}

\section{A. Algoritma Penentuan Lokasi Lot Parkir} Pengunjung

Algoritma dalam menentukan lokasi lot parkir pengunjung berdasarkan outlet yang akan dikunjungi dapat dilihat pada Gambar 1. Pada Gambar 1 dapat dilihat bahwa lokasi kunjungan merupakan input dari sistem. Setiap lokasi kunjungan diasumsukan memiliki titik koordinat, yaitu garis longitude $(X)$ dan garis latitude $(Y)$. Hal yang sama juga berlaku untuk lot parkir yang memiliki titik koordinat.

Euclidean distance digunakan untuk menghitung jarak antara titik lokasi kunjungan dengan titik lot parkir. Proses perhitungan jarak dapat dilihat pada (1).

$D\left(O_{i}, L_{j}\right)=\sqrt{\left(X_{O_{i}}-X_{L_{j}}\right)^{2}+\left(Y_{O_{i}}-Y_{L_{j}}\right)^{2}}$

dimana:

$D\left(O_{i}, L_{j}\right)=$ jarak antara outlet ke- $i$ dan lot parkir ke-j

$X_{O_{i}} \quad=$ titik longitude outlet $\mathrm{ke}-i$

$X_{L_{j}} \quad=$ titik longitude lot parkir ke-j

$Y_{O_{i}} \quad=$ titik latitude outlet $\mathrm{ke}-i$

$Y_{L_{j}} \quad=$ titik latitude outlet $\mathrm{ke}-j$
Lot parkir terdekat diperoleh dengan mencari nilai jarak terkecil antara outlet yang akan dikunjungi dengan seluruh lot parkir yang masih tersedia. Setelah diperoleh lokasi lot parkir dengan jarak terdekat maka lokasi lot parkir tersebut akan ditampilkan pada pengunjung dan dikunci oleh sistem.

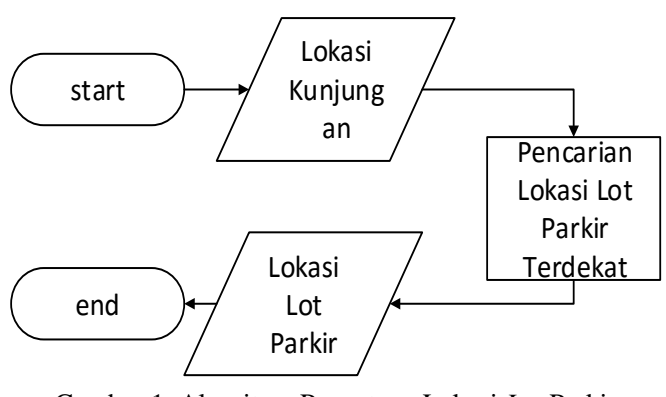

Gambar 1. Algoritma Penentuan Lokasi Lot Parkir

\section{B. Model Lot Parkir}

Model denah parkir yang digunakan pada penelitian ini berbentuk persegi panjang dimana outlet berada pada bagian tengah dan lot parkir mengelilingi outlet yang tersedia. Model lot parkir dapat dilihat pada Gambar 2.

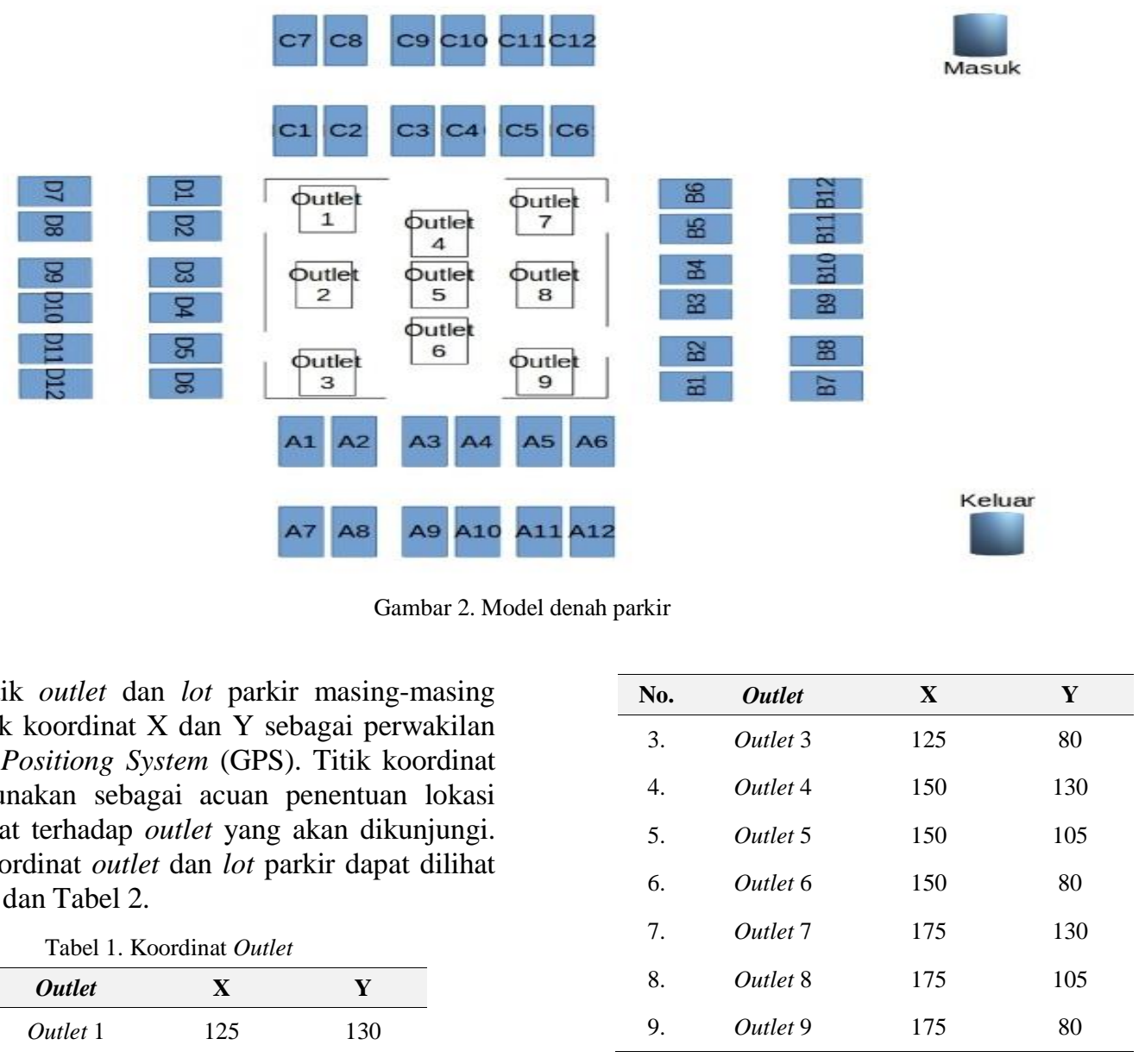

Setiap titik outlet dan lot parkir masing-masing diberikan titik koordinat X dan Y sebagai perwakilan nilai Global Positiong System (GPS). Titik koordinat tersebut digunakan sebagai acuan penentuan lokasi parkir terdekat terhadap outlet yang akan dikunjungi. Titik-titik koordinat outlet dan lot parkir dapat dilihat pada Tabel 1 dan Tabel 2.

\begin{tabular}{cccc}
\multicolumn{4}{c}{ Tabel 1. Koordinat Outlet } \\
\hline No. & Outlet & X & Y \\
\hline 1. & Outlet 1 & 125 & 130 \\
2. & Outlet 2 & 125 & 105
\end{tabular}




\begin{tabular}{|c|c|c|c|c|c|c|c|}
\hline No. & Lot & $\mathbf{X}$ & $\mathbf{Y}$ & No. & Lot & $\mathbf{X}$ & $\mathbf{Y}$ \\
\hline 1. & A1 & 120 & 50 & 25. & $\mathrm{C} 1$ & 180 & 160 \\
\hline 2. & $\mathrm{~A} 2$ & 130 & 50 & 26. & $\mathrm{C} 2$ & 170 & 160 \\
\hline 3. & A3 & 145 & 50 & 27. & $\mathrm{C} 3$ & 155 & 160 \\
\hline 4. & A4 & 155 & 50 & 28. & $\mathrm{C} 4$ & 145 & 160 \\
\hline 5. & A5 & 170 & 50 & 29. & C5 & 130 & 160 \\
\hline 6. & A6 & 180 & 50 & 30. & C6 & 120 & 160 \\
\hline 7. & A7 & 120 & 30 & 31. & C7 & 180 & 180 \\
\hline 8. & A8 & 130 & 30 & 32. & $\mathrm{C} 8$ & 170 & 180 \\
\hline 9. & A9 & 145 & 30 & 33. & C9 & 155 & 180 \\
\hline 10. & A10 & 155 & 30 & 34. & C10 & 145 & 180 \\
\hline 11. & A11 & 170 & 30 & 35. & C11 & 130 & 180 \\
\hline 12. & A12 & 180 & 30 & 36. & $\mathrm{C} 12$ & 120 & 180 \\
\hline 13. & B1 & 210 & 75 & 37. & D1 & 95 & 135 \\
\hline 14. & B2 & 210 & 85 & 38. & D2 & 95 & 125 \\
\hline 15. & B3 & 210 & 100 & 39. & D3 & 95 & 110 \\
\hline 16. & B4 & 210 & 110 & 40. & D4 & 95 & 100 \\
\hline 17. & B5 & 210 & 125 & 41. & D5 & 95 & 85 \\
\hline 18. & B6 & 210 & 135 & 42. & D6 & 95 & 75 \\
\hline 19. & B7 & 230 & 75 & 43. & D7 & 75 & 135 \\
\hline 20. & B8 & 230 & 85 & 44. & D8 & 75 & 125 \\
\hline 21. & B9 & 230 & 100 & 45. & D9 & 75 & 110 \\
\hline 22. & B10 & 230 & 110 & 46. & D10 & 75 & 100 \\
\hline 23. & B11 & 230 & 125 & 47. & D11 & 75 & 85 \\
\hline 24. & B12 & 230 & 135 & 48. & D12 & 75 & 75 \\
\hline
\end{tabular}

\section{HASIL DAN PEMBAHASAN}

\section{A. Hasil Observasi Sistem Parkir Mal di Kota Makassar}

Hasil observasi sitem parkir pada 3 (tiga) lokasi mal menunjukkan permasalahan yang sama, yaitu yakni sulitnya mencari tempat parkir dan tidak adanya layanan informasi untuk penentuan tempat parkir pada saat masuk. Permasalahan tersebut menyebabkan pengunjung kesulitan mencari tempat parkir. Kondisi yang dapat terjadi lainnya adalah lokasi parkir yang dijadikan tujuan dapat ditempati lebih dahulu oleh pengunjung lain sehingga pengemudi harus berputar untuk mencari tempat lain. Hal ini menyebabkan kemacetan pada gedung parkir yang nantinya akan menyebabkan polusi udara di dalam gedung tersebut.

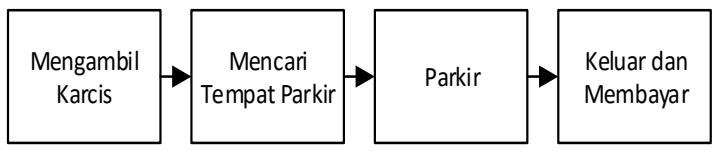

Gambar 3. Proses Sistem Parkir Mal di Kota Makassar
Pada Gambar 3 dapat dilihat proses sistem parkir mal dimana pengunjung terlebih dahulu mengambil karcis di tempat pengambilan karcis. Setelah pendataan plat nomor kendaraan dan karcis parkir tercetak, pengemudi akan mencari lot parkir. Saat kunjungan selesai, pengemudi keluar dari lot parkir dan menuju pos keluar untuk menyerahkan karcis parkir dan membayar biaya parkir berdasarkan waktu kunjungan. Pada proses tersebut dapat dilihat bahwa sistem yang digunakan tidak menyediakan layanan untuk pengunjung memilih lot parkir berdasarkan lokasi kunjungannya.

Berdasarkan hasil observasi, maka dapat diperoleh permasalahan dari sistem parkir saat ini adalah pengunjung kesulitan dalam memilih lokasi lot parkir disebabkan tidak adanya layanan informasi yang membantu pengunjung. Dalam mengatasi permasalahan yang tersedia maka dibutuhkan adanya sebuah sistem yang dapat membantu pengunjung untuk memperoleh informasi lokasi lot parkir berdasarkan lokasi kunjungannya sehingga diusulkan 
sebuah sistem parkir mal yang menggunakan Arduino Uno dan RFID.

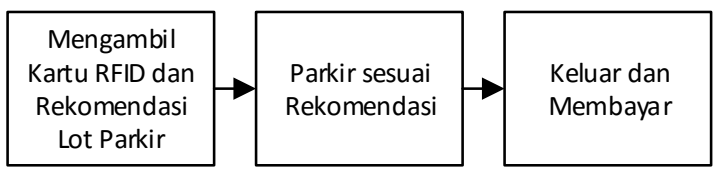

Gambar 4. Usulan Proses Sistem Parkir Mal di kota Makassar

Pada Gambar 4, pengunjung ketika memasuki mal terlebih dahulu memasukkan outlet kunjungannya. Setelah itu, pengunjung akan memperoleh kartu RFID serta lokasi lot parkir yang terdekat dari outlet yang akan dikunjungi. Kartu RFID digunakan sebagai pengganti karcis parkir saat ini dan digunakan sebagai penanda bagi setiap kendaraan. Lot parkir yang direkomendasikan oleh sistem kemudian akan terkunci.

Setelah pengunjung memarkir kendaraannya pada lot yang telah dikunci maka pengunjung wajib menempelkan kartu RFID untuk mengkonfirmasi bahwa lot tersebut ditempati oleh kendaraan yang telah didata. Apabila lot parkir yang telah dikunci ditempati oleh kendaraan yang berbeda maka alarm akan berbunyi dan hanya akan berhenti apabila kartu RFID yang tepat ditempel pada lot parkir tersebut. Setelah kunjungan selesai, pengunjung keluar kemudian memberikan kartu RFID pada pos keluar dan membayar biaya parkir.

\section{B. Perancangan Prototype Sistem Parkir}

Prototype sistem parkir yang dirancang menggunakan Arduino Uno. Sketsa prototype pada pos masuk/keluar dan lot parkir dapat dilihat pada Gambar 5 dan 6. Pada pos masuk/keluar (Gambar 5) hanya terdapat RFID RFC-522 Module sebagai pembaca kartu RFID yang digunakan petugas untuk menempelkan kartu RFID yang akan diberikan kepada pengunjung saat masuk dan diberikan oleh pengunjung saat keluar.

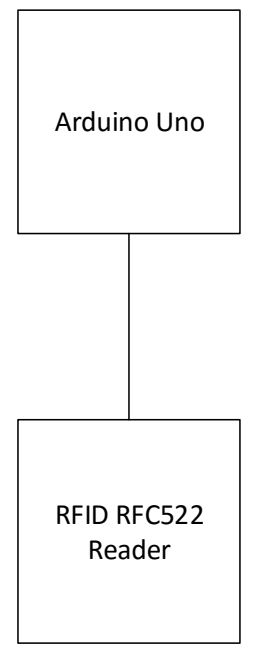

Gambar 5. Diagram Blok Prototype Pada Pos Masuk/Keluar
Pada setiap lot parkir menggunakan sensor Light Dependent Resistor (LDR) untuk mendeteksi apakah terdapat kendaraan yang sedang parkir atau tidak, RFID RFC-522 Module sebagai pembaca kartu RFID, buzzer untuk alarm, dan LED 2 warna sebagai penanda status lot saat ini apakah lot tersebut terisi (merah) atau tidak (hijau). Diagram blok prototype pada setiap lot parkir dapat dilihat pada Gambar 6 .

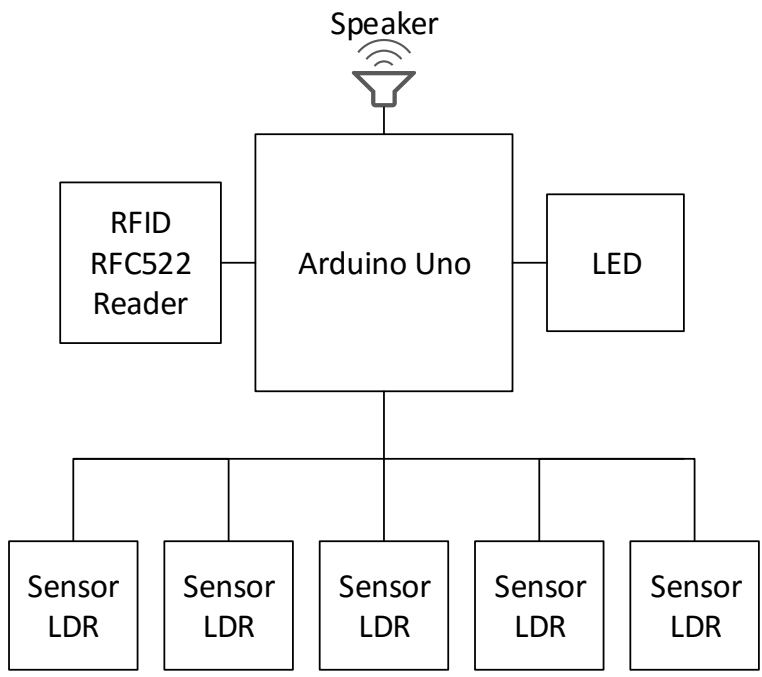

Gambar 6. Diagram Blok Prototype Pada Lot Parkir

\section{Perancangan Database}

Perancangan database bertujuan untuk menampung data dari aktivitas parkir, koordinat lot parkir, status lot parkir, dan koordinat outlet. Hal ini bertujuan untuk mempermudah sistem untuk menghitung jarak terdekat untuk memberikan lokasi terdekat dari outlet yang ingin dikunjung serta perhitungan biaya parkir kendaraan. Hasil perancangan database dapat dilihat pada Gambar 7.

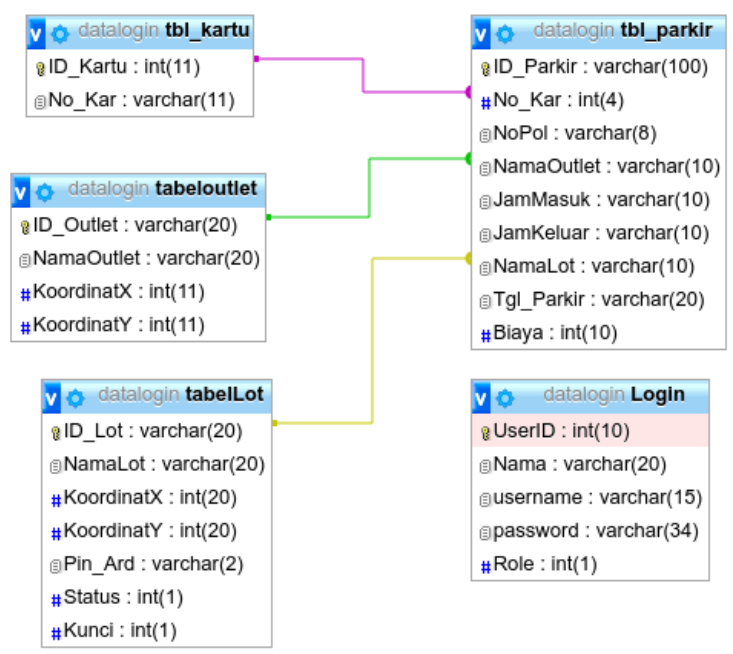

Gambar 7. Struktur Database Sistem Parkir Mal 


\section{Perancangan Aplikasi Parkir}

Aplikasi parkir dirancang berdasarkan hasil perancangan sistem usulan. Alur kerja sistem parkir usulan dirancang dengan menggunakan Use Case Diagram pada Gambar 8. Aplikasi sistem parkir dirancang dengan menggunakan bahasa pemrograman Java dan database engine MySQL.

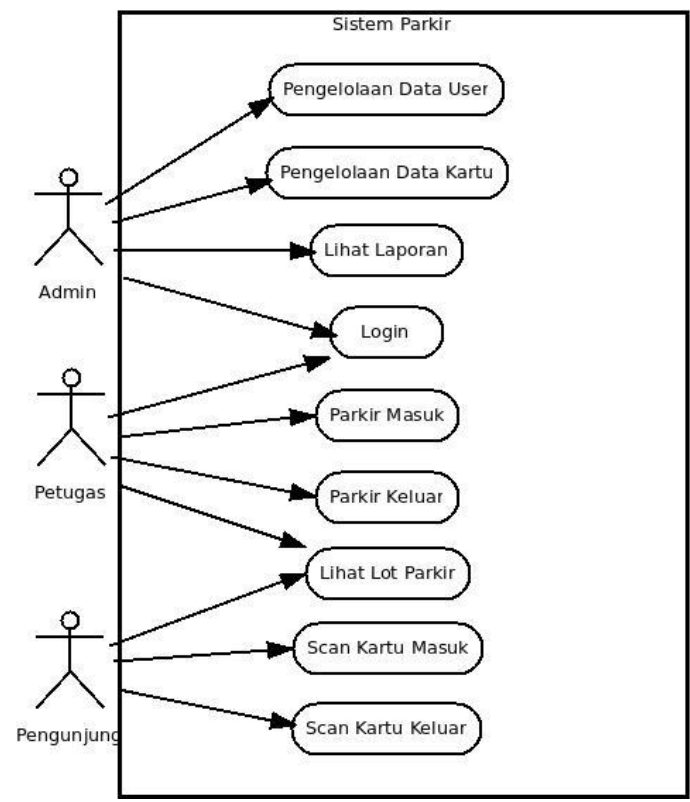

Gambar 8. Use Case Diagram Sistem Parkir Mal

Aplikasi parkir yang dirancang hanya dikhususkan untuk pengunjung, petugas parkir, dan admin. Pengunjung menggunakan sistem parkir untuk melakukan scan kartu masuk/keluar dan melihat informasi lot parkir. Sedangkan petugas memiliki tugas untuk menambah user, melakukan transaksi parkir masuk/keluar, dan menampilkan lokasi parkir. Admin bertugas untuk pengelolaan data user, kartu, dan laporan parkir.

\section{E. Pengujian/Simulasi Sistem Parkir}

Pengujian hasil rancangan sistem parkir yang diusulkan dilakukan dalam bentuk simulasi. Simulasi akan dilakukan menyerupai proses parkir yang terjadi secara nyata sesuai dengan alur proses pada Gambar 4. Pada Gambar 9 dapat dilihat tampilan aplikasi yang memberikan informasi lokasi outlet dan lot parkir.

Pada Gambar 9, kotak ungu menunjukkan outlet dan kotak hijau menunjukkan lot yang sedang kosong. Lampu LED untuk setiap lot parkir akan berwarna hijau yang menunjukkan lot sedang kosong (Gambar 10).

Pada saat pengunjung datang, petugas parkir akan mencatat nomor polisi dan outlet yang menjadi lokasi pengunjung ke dalam sistem. Petugas kemudian akan melakukan scan dan memberikan kartu RFID kepada pengunjung (Gambar 11).

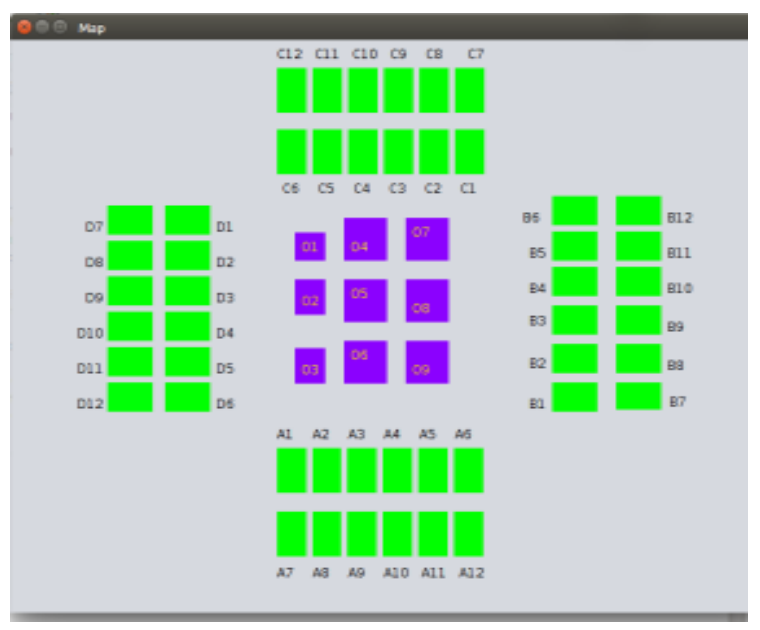

Gambar 9. Tampilan Informasi Lokasi Outlet dan Lot Parkir

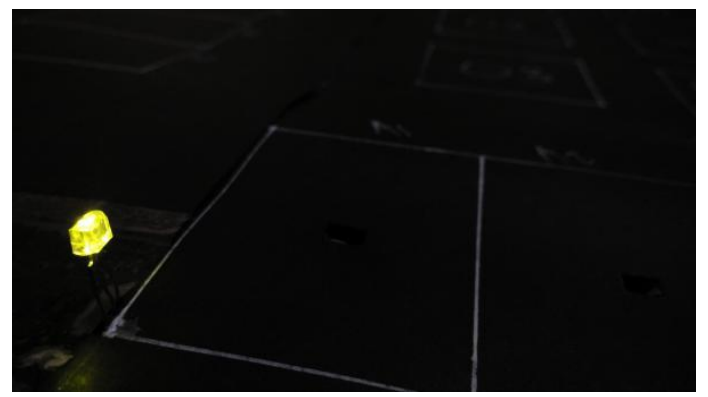

Gambar 10. Lot Kosong Dengan LED Berwarna Hijau

Pengunjung yang telah memperoleh kartu RFID kemudian dapat melihat lokasi lot parkir yang terdekat dari lokasi kunjungannya. Pada Gambar 12, kondisi yang disimulasikan adalah pengunjung akan mengunjungi outlet 3 dikunjungi sehingga sistem memberikan rekomendasi lokasi lot parkir A1.

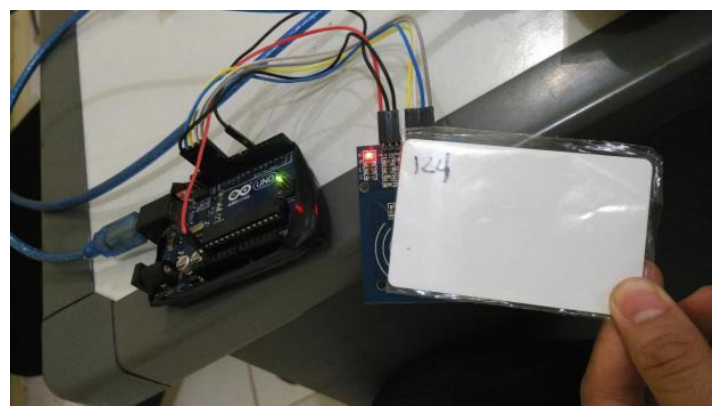

Gambar 11. Tampilan Scanning Kartu RFID Oleh Petugas Parkir

Ketika scanning kartu RFID dilakukan oleh petugas parkir ke dalam aplikasi, secara otomatis sistem parkir akan memberikan rekomendasi lot parkir terdekat. Sebagai contoh, seorang pengunjung akan mengunjungi outlet 3 (O3) maka akan dilakukan perhitungan jarak terhadap lot parkir sektor A yang belum tersedia dengan menggunakan (1).

$$
\begin{aligned}
& D(O 3, A 1)=\sqrt{(125-120)^{2}+(80-50)^{2}}=30,4138 \\
& D(O 3, A 2)=\sqrt{(125-130)^{2}+(80-50)^{2}}=30,4138 \\
& D(O 3, A 3)=\sqrt{(125-145)^{2}+(80-50)^{2}}=36,0555 \\
& D(O 3, A 4)=\sqrt{(125-155)^{2}+(80-50)^{2}}=42,4264
\end{aligned}
$$


$D(O 3, A 5)=\sqrt{(125-170)^{2}+(80-50)^{2}}=54,0833$

$D(O 3, A 6)=\sqrt{(125-180)^{2}+(80-50)^{2}}=62,6498$

$D(O 3, A 7)=\sqrt{(125-120)^{2}+(80-30)^{2}}=50,2494$

$D(O 3, A 8)=\sqrt{(125-130)^{2}+(80-30)^{2}}=50,2494$

$D(O 3, A 9)=\sqrt{(125-145)^{2}+(80-30)^{2}}=53,8517$

$D(O 3, A 10)=\sqrt{(125-155)^{2}+(80-30)^{2}}=58,3095$

$D(O 3, A 11)=\sqrt{(125-170)^{2}+(80-30)^{2}}=67,2681$

$D(O 3, A 12)=\sqrt{(125-180)^{2}+(80-30)^{2}}=74,3303$

Proses perhitungan yang sama juga berlaku untuk lot parkir sektor B, C, dan D. Setelah mendapatkan nilai jarak dari setiap lot terhadap outlet maka hasil tersebut akan dibandingkan satu persatu sampai mendapat nilai jarak terkecil pertama yang sedang tidak terisi. Pada perhitungan dari kasus pengunjung akan mengunjungi outlet 3 didapatkan lot A1 dan A2 memiliki nilai terkecil yakni 30,4138. Sistem akan melakukan pengecekan status lot tersebut, apakah kosong atau sedang terisi. Apabila status lot kosong, maka sistem akan memberikan rekomendasi tempat parkir pada lot tersebut. Tampilan hasil rekomendasi lokasi lot parkir dapat dilihat pada Gambar 12.

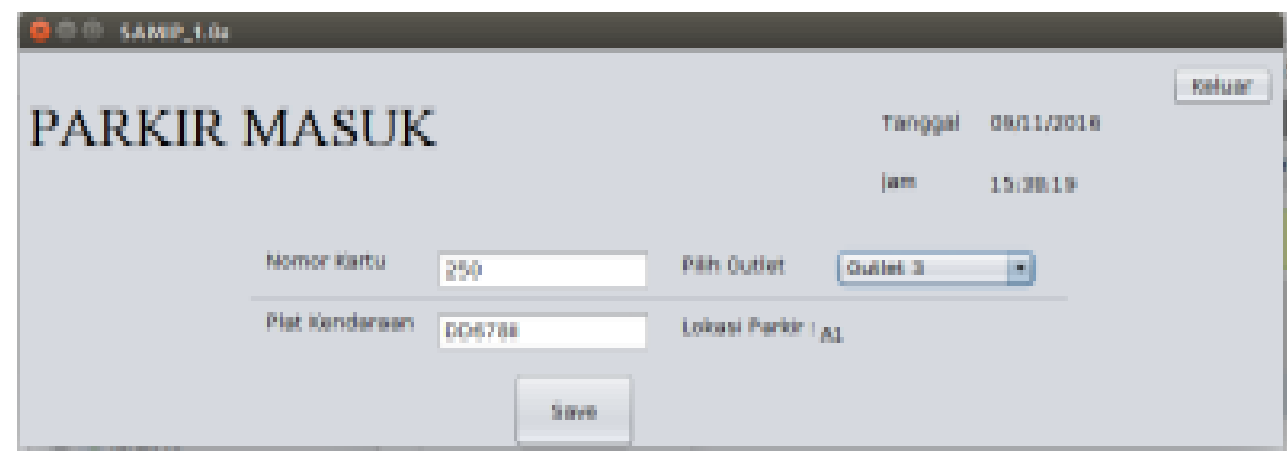

Gambar 12. Tampilan Hasil Rekomendasi Lokasi Lot Parkir

Aplikasi kemudian menampilkan informasi lot parkir yang direkomendasikan menjadi kotak biru (Gambar 13). Lot parkir dengan warna biru menunjukkan bahwa lot parkir tersebut telah terkunci.

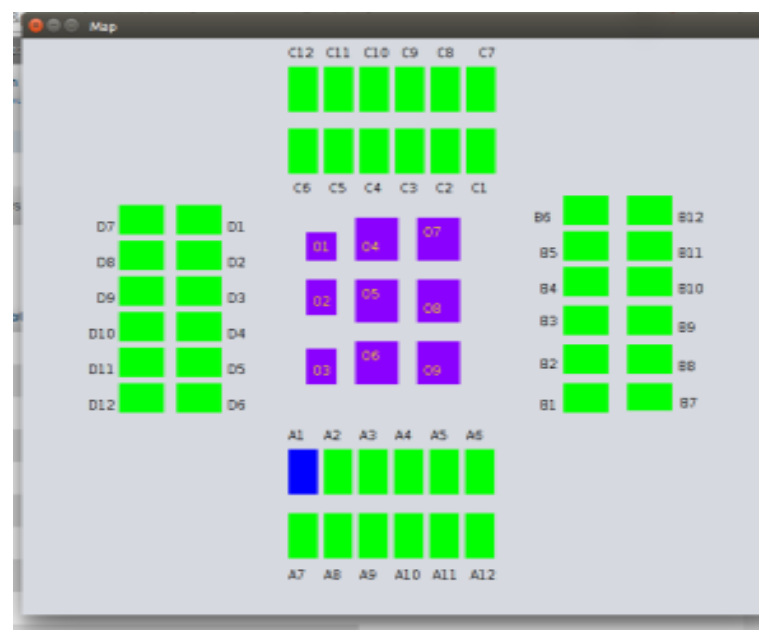

Gambar 13. Tampilan Informasi Lot Parkir A1 yang Terkunci

Apabila lot parkir terkunci (Gambar 14), LED pada lot akan berubah menjadi warna kuning dan alarm akan berbunyi ketika kendaraan parkir pada lot tersebut. Alarm akan berhenti berbunyi apabila telah dilakukan scan kartu RFID pada lot tersebut. Apabila kartu RFID sesuai maka alarm akan mati dan lampu LED berubah menjadi warna merah (Gambar 15).

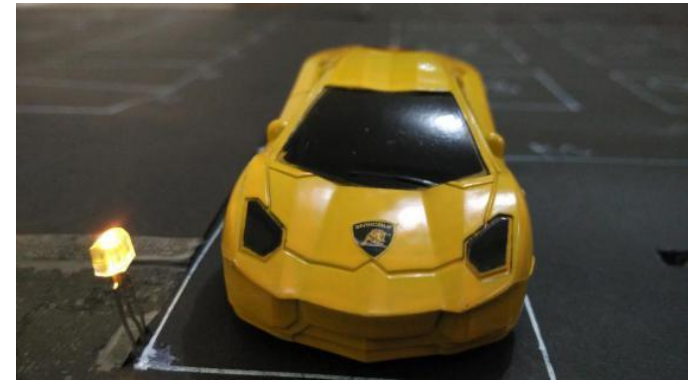

Gambar 14. Lot Terkunci dengan LED Berwarna Kuning

Setelah lot ditempati dengan kendaraan yang sesuai maka tampilan lot tersebut akan menjadi berwarna merah pada aplikasi. Lot yang telah ditempati tidak akan dimasukkan dalam penentuan lokasi lot parkir terdekat ketika pengunjung lain hendak mencari tempat parkir. Sebagai contoh, seorang pengunjung hendak juga mengunjungi outlet 3 maka sistem akan memberikan lokasi lot A2 dikarenakan lot A1 telah ditempati (Gambar 16).

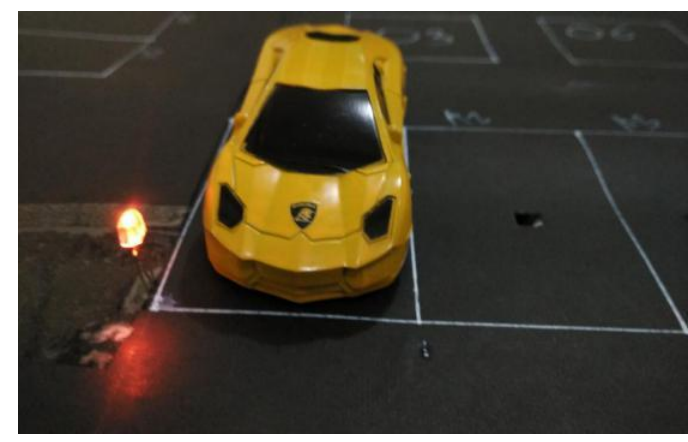

Gambar 15. Lot Ditempati dengan LED Berwarna Merah 
Berdasarkan skenario kunjungan user ke mal dapat dilihat bahwa rekomendasi lokasi lot parkir adalah lokasi lot parkir terdekat dari outlet yang akan dikunjungi oleh pengunjung. Dengan adanya pemberian rekomendasi lokasi lot parkir maka akan membantu user dalam mencari tempat parkir terdekat dari outlet yang akan dikunjungi. Hal ini berdampak pada antrian user dalam mencari lokasi parkir dapat diminimalisasikan karena setiap user telah memperoleh rekomendasi lot parkir yang disediakan oleh aplikasi parkir.

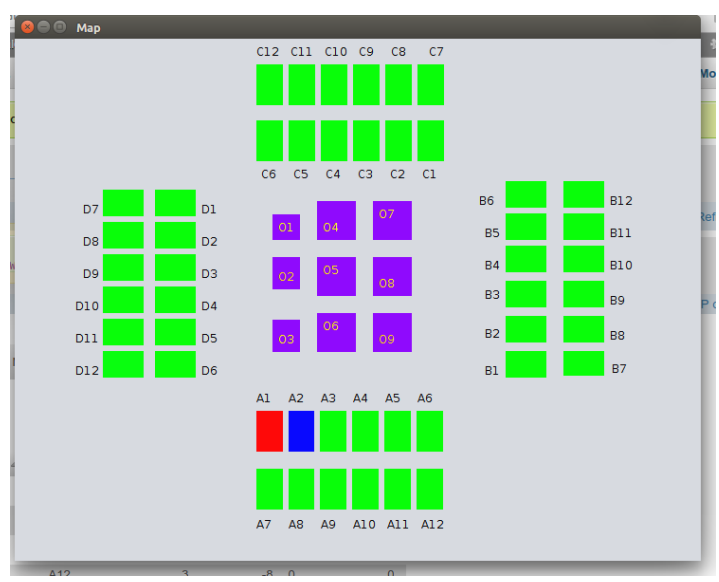

Gambar 16. Tampilan Informasi Lot Parkir A2 yang Terkunci
Hasil pengujian dengan melibatkan 10 skenario dapat dilihat pada Tabel 3. Pada Tabel 3 dapat dilihat bahwa pada Skenario II, Skenario VI, dan Skenario $\mathrm{X}$, lokasi lot terdekat dengan lot yang direkomendasikan oleh sistem berbeda. Hal ini disebabkan karena lot terdekat dari outlet yang akan dikunjungi telah ditempati oleh pengendara yang lain. Sistem telah mempertimbangkan apakah sebuah lot parkir telah ditempati atau tidak. Apabila lot terdekat telah ditempati maka sistem akan memberikan rekomendasi kepada pengguna berupa lot parkir terdekat berikutnya.

Pada Tabel 3, apabila pengguna hanya mencari lot terdekat saja maka persentase ketersediaan lot parkir terdekat dengan outlet yang akan dikunjungi berdasarkan skenario yang diuji adalah sebesar $70 \%$. Hasil pengujian sistem terhadap skenario yang diuji menunjukkan persentase ketersediaan lot parkir terdekat dengan outlet yang akan dikunjungi adalah sebesar $100 \%$. Hal ini disebabkan karena sistem dirancang dengan mempertimbangkan jarak antara lot dengan outlet tujuan dan status ketersediaan lot terdekat. Apabila lot terdekat telah ditempati maka sistem secara otomatis akan memberikan rekomendasi lot terdekat berikutnya kepada pengguna.

Tabel 3. Skenario Pengujian Pencarian Lot Parkir

\begin{tabular}{|c|c|c|c|c|c|c|c|}
\hline No. & Skenario & $\begin{array}{c}\text { Outlet } \\
\text { Tujuan }\end{array}$ & Lot Terpakai & $\begin{array}{c}\text { Lot } \\
\text { Terdekat }\end{array}$ & $\begin{array}{c}\text { Status } \\
\text { Lot } \\
\text { Terdekat }\end{array}$ & $\begin{array}{c}\text { Rekomendasi } \\
\text { Lot }\end{array}$ & $\begin{array}{c}\text { Status } \\
\text { Rekomendasi } \\
\text { Lot }\end{array}$ \\
\hline 1. & Skenario I & $\mathrm{O} 3$ & - & A1 & $\sqrt{ }$ & A1 & $\sqrt{ }$ \\
\hline 2. & Skenario II & $\mathrm{O} 3$ & $\mathrm{~A} 1$ & A1 & $x$ & $\mathrm{~A} 2$ & $\sqrt{ }$ \\
\hline 3. & Skenario III & $\mathrm{O} 2$ & $\mathrm{~A} 1, \mathrm{~A} 2$ & D3 & $\sqrt{ }$ & D3 & $\sqrt{ }$ \\
\hline 4. & Skenario IV & O6 & $\mathrm{A} 1, \mathrm{~A} 2, \mathrm{D} 3$ & A3 & $\sqrt{ }$ & A3 & $\sqrt{ }$ \\
\hline 5. & Skenario V & O7 & $\mathrm{A} 1, \mathrm{~A} 2, \mathrm{~A} 3, \mathrm{D} 3$ & $\mathrm{C} 1$ & $\sqrt{ }$ & $\mathrm{C} 1$ & $\sqrt{ }$ \\
\hline 6. & Skenario VI & O5 & $\mathrm{A} 1, \mathrm{~A} 2, \mathrm{~A} 3, \mathrm{C} 1, \mathrm{D} 3$ & A3 & $x$ & A4 & $\sqrt{ }$ \\
\hline 7. & Skenario VII & $\mathrm{O} 8$ & $\mathrm{~A} 1, \mathrm{~A} 2, \mathrm{~A} 3, \mathrm{~A} 4, \mathrm{C} 1, \mathrm{D} 3$ & B3 & $\sqrt{ }$ & B3 & $\sqrt{ }$ \\
\hline 8. & Skenario VIII & $\mathrm{O} 1$ & $\mathrm{~A} 1, \mathrm{~A} 2, \mathrm{~A} 3, \mathrm{~A} 4, \mathrm{~B} 3, \mathrm{C} 1, \mathrm{D} 3$ & $\mathrm{C} 5$ & $\sqrt{ }$ & $\mathrm{C} 5$ & $\sqrt{ }$ \\
\hline 9. & Skenario IX & O9 & $\mathrm{A} 1, \mathrm{~A} 2, \mathrm{~A} 3, \mathrm{~A} 4, \mathrm{~B} 3, \mathrm{C} 1, \mathrm{C} 5, \mathrm{D} 3$ & A5 & $\sqrt{ }$ & A5 & $\sqrt{ }$ \\
\hline 10. & Skenario X & O9 & $\mathrm{A} 1, \mathrm{~A} 2, \mathrm{~A} 3, \mathrm{~A} 4, \mathrm{~A} 5, \mathrm{~B} 3, \mathrm{C} 1, \mathrm{C} 5, \mathrm{D} 3$ & A5 & $x$ & A6 & $\sqrt{ }$ \\
\hline
\end{tabular}

\section{PENUTUP}

\section{A. Kesimpulan}

Sistem parkir mal yang dirancang telah dapat memberikan lokasi lot parkir terdekat berdasarkan lokasi kunjungan dari pengunjung dengan menggunakan Arduino Uno dan RFID sebagai pengenal identitas user dengan persentase ketersediaan lot parkir terdekat dengan outlet yang akan dikunjungi adalah sebesar $100 \%$. Penentuan lot parkir terdekat dengan menggunakan euclidean distance dan status ketersediaan lot terdekat akan menghasilkan lokasi lot parkir yang terdekat dengan outlet kunjungan user. Dengan adanya informasi lokasi lot parkir kepada pengunjung dapat mencegah terjadinya antrian kendaraan user yang sedang mencari lokasi lot parkirnya.

\section{B. Saran}

Denah tempat parkir yang didesain pada penelitian ini mengasumsikan mal yang hanya memiliki 1 (satu) lantai. Pada penelitian berikutnya sebaiknya dapat didesain tempat parkir untuk mengakomodasi mal yang memiliki banyak lantai. 


\section{DAFTAR PUSTAKA}

[1] Jasa Prima. (2015) Website Jasa Prima. [Online], http://jasaprima134.blogspot.co.id/2015/04/bab-iiperan-mall-sebagai-ruang-publik.html, tanggal akses 7 April 2017.

[2] G. Ongkowijoyo, M. Hartono., and R. Meitha, "Pengintegrasian Kansei Engineering dan Customer Relationship Management untuk Meningkatkan Kualitas Layanan di Mall Ciputra World Surabaya," Calyptra: Jurnal Ilmiah Mahasiswa Universitas Surabaya, Vol. 1 No. 1, hal. 1-15, 2012.

[3] E. Usada, Y. Yuniarsyah, and D. M. Choiriah, "Rancang Bangun Sistem Informasi Penitipan Motor Berbasis Web Dengan Menggunakan PHP Dan MYSQL Di Terminal Purwokerto," Jurnal Informatika, Telekomunikasi, dan Elektronika (INFOTEL), Vol. 4 No. 1, hal 42-51, 2012.

[4] E. Noviaty, "Perancangan Aplikasi Sistem Parkir Berbasis Java dengan Barcode pada Universitas Atma Jaya Makassar," S.Kom., Undergraduate Thesis, Universitas Atma Jaya Makassar, 2012.

[5] V. Habsyah, Y. Christyono, and I. Santoso, "Aplikasi Sistem Parkir dengan Automatisasi Pembiayaan Berbasis RFID (Radio Frequency Identification)," TRANSMISI, Vol. 13 No. 3, hal 108-113, 2011.

[6] Alpiriyandi, "Sistem Perparkiran secara Visual Map Berbasis Local Area Network," S.Kom., Undergraduate Thesis, Universitas Sumatera Utara, 2012.
[7] A. Anindita, Sudjadi, and Darjat, "Sistem Informasi Area Parkir Berbasis Mikrokontroler ATMEGA 16," TRANSMISI, Vol. 13 No. 3, hal 132-137, 2013.

[8] I. Winarsih, and R. Mahendra, "Sistem Parkir Otomatis Menggunakan RFID Berbasiskan Mikrokontroler AT 89S51," Jurnal Teknik Elektro JETri, Vol. 8 No. 2, hal 21-36, 2009.

[9] H. A. Prasetyo, and E. Usada, "Perancangan Sistem Pintu Gerbang dengan Sensor Radio Frequency Identification (RFID) menggunakan Metode Waterfall," Jurnal Informatika, Telekomunikasi, dan Elektronika (INFOTEL), Vol. 5 No. 2, hal 24-32, 2013.

[10] D. Yulianto, and H. Yuliansyah, "Rancang Bangun Aplikasi Traffic Counter RFID," Jurnal Nasional Teknik Elektro dan Teknologi Informasi (JNTETI), Vol. 4 No. 1, hal 32-38, 2015.

[11] A.B. Tjandrarini, and J. Lemantara, "Pembuatan Prototipe Tempat dan Aplikasi Pengembalian Koleksi Perpustakaan Secara Mandiri," Jurnal Nasional Teknik Elektro dan Teknologi Informasi (JNTETI), Vol. 4 No. 1, hal 1-9, 2015.

[12] S. K. Astuti, "Analisis Pencemaran Udara Akibat Emisi Kendaraan Bermotor Pada Parkir Basement (Studi Kasus : Mal X),” ST., Undergraduate Thesis, Universitas Indonesia, 2010.

[13] I. E. Dewanti, J. Arifin, and D. Kurnianto, "Rancang Bangun Pendingin Perangkat Telekomunikasi Otomatis Berbasis Arduino Uno," Seminar Nasional Sains dan Teknologi 7, Semarang, 2016. 